\title{
MANAJEMEN PENDIDIKAN PONDOK PESANTREN AL FALAH BANJARBARU DI MASA PANDEMI COVID-19
}

\author{
Riinawati \\ UIN Antasari, Banjarmasin \\ $\underline{\text { riinawati2021@gmail.com }}$
}

\begin{abstract}
ABSTRAK
Saat ini, perbincangan mengenai Covid-19 masih terus menghangat di tengah masyarakat. Pandemi Covid19 yang melanda sejak awal tahun 2020 memberikan dampak pada berbagai sektor kehidupan. Berbagai sektor dituntut untuk melakukan adaptasi dengan datanganya pandemi tersebut sebagai upaya bertahan. Salah satu sektor yang terdampak yaitu lembaga pendidikan pesantren. Pesantren ialah sebuah bangku pendidikan dimana menonjolkan sisi pendidikan agama dalam keseharian. Pesantren memiliki kekhasan dan karakteristik tersendiri pada sistem pendidikan yang digunakan. Pada masa pandemi ini, pondok pesantren Al-Falah Banjarbaru sebagai tempat berkumpul para santri dari berbagai daerah juga dituntut untuk beradaptasi dengan adanya pandemi. Kebijakan-kebijakan terus dirundingkan sebagai bentuk pertahanan di masa pandemi ini. Manajemen pada pondok pesantren Al-Falah Banjarbaru seperti pengelolaan dan sistem belajar juga harus diubah dengan inovasi dan kreativitas baru yang dikembangkan untuk keselamatan dan kebaikan pada saat ini. Munculnya pandemi tentunya menimbulkan banyak problematika seperti terbatasnya ruang dan melemahnya kegiatan pembelajaran yang efektif. Pesantren pun menerapkan manajemen yang cukup berbeda dari sebelumnya seperti peralihan proses belajar mengajar menjadi daring ataupun membatasi kegiatan yang menyebabkan kerumuman. Walau bagaimanapun, kegiatan dan aktivitas dalam pondok pesantren harus tetap berjalan stabil dengan berbagai pertimbangan untuk kebaikan bersama.
\end{abstract}

Kata kunci: manajemen pondok; pandemi Covid-19; pesantren

\begin{abstract}
Currently, the discussion about Covid-19 is still hot in the community. The Covid-19 pandemic that has hit since the beginning of 2020 has had an impact on various sectors of life. Various sectors are required to adapt to the arrival of the pandemic as an effort to survive. One of the sectors affected is Islamic boarding schools. Islamic boarding school is an educational bench which emphasizes the side of religious education in everyday life. Islamic boarding schools have their own peculiarities and characteristics in the education system used. During this pandemic, the Al-Falah Banjarbaru Islamic boarding school as a gathering place for students from various regions is also required to adapt to the pandemic. Policies continue to be negotiated as a form of defense during this pandemic. Management at the Al-Falah Islamic boarding school Banjarbaru such as management and learning systems must also be changed with new innovations and creativity developed for safety and goodness at this time. The emergence of a pandemic certainly raises many problems such as limited space and the weakening of effective teaching and learning activities. Therefore, Islamic boarding schools implement management that is quite different from before, such as switching the teaching and learning process to online or limiting activities that cause crowds. However, activities and activities in Islamic boarding schools must continue to run stably with various considerations for the common good.
\end{abstract}

Keywords: boarding school management; Covid-19 pandemic; Islamic boarding school

\section{Pendahuluan}

Untuk meningkatkan ilmu agama dan memperdalam ilmu agama khususnya agama Islam terdapat sebuah lembaga yaitu pesantren.
Pesantren sendiri dapat dikatakan sebagai tempat untuk mendalami ilmu agama dimana didalamnya bertumbuh para alim, abid, dan cendekia. Apabila ditinjau rinci maka pendidikan di pesantren 


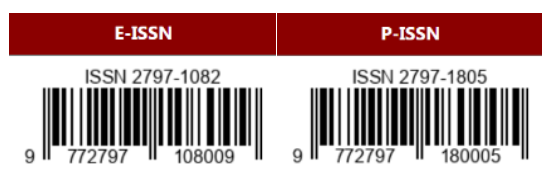

memiliki tujuan untuk meningkatkan budi pekerti, meningkatkan semangat, melatih sikap menghargai, memperdalam nilai spritual, menonjolkan sisi kemanusiaan, membangun sikap jujur dan bermoral, serta upaya mempersiapkan santri agar menjadi sosok sederhana dengan hati yang bersih. Pondok pesantren ini sering menjadi tumpuan masyarakat (social focus) sebagai lembaga pendidikan Islam yang berfungsi untuk menanamkan iman dan mempertebal ketaqwaan terhadap Allah SWT (Kafrawi, 1978). Pesantren adalah lembaga yang bisa dikatakan merupakan wujud proses wajar perkembangan sistem pendidikan nasional. Dalam historis pesantren tidak hanya identik dengan makna keislaman, tetapi juga mengandung makna keaslian Indonesia (Indigenous). Sebab, lembaga yang serupa pesantren ini sebenarnya sudah ada sejak pada masa kekuasaan Hindu-Budha. Sehingga Islam tinggal meneruskan dan mengislamkan lembaga yang sudah ada (Nurcholis, 1997). Sistem manajemen pendidikan dan pengelolaan kehidupan yang diterapkan di pesantren memiliki keunikan tersendiri dan cukup berbeda dari pendidikan formal. Terdapat perbedaan pada berbagai tatanan, jadwal juga pembelajaran yang disampaikan, namun jika ditinjau dari tujuan pendidikan secara umum maka lembaga pendidikan pesantren dan lembaga pendidikan formal memiliki tujuan pembelajaran yang sama yakni untuk mewujudkan peserta didik yang lebih bermoral dan cerdas intelektual serta berkarakter (Sunaryo, 2020)

Dalam semua dimensi waktu, perjalanan kisah dalam kehidupan pesantren pasti dan selalu menemui tantangan-tangangan juga persoalan yang harus dihadapi. Berbagai persoalan dan masalah yang terjadi tersebut harus mampu diatasi oleh pengelola pesantren agar tetap dapat menjaga iklim pesantren yang damai. Bahkan seiring berjalannya waktu, pesantren dituntut untuk menjawab tantangan akibat perubahan pada segala bidang sebagai indikator dalam mengukur kemampuan pesantren menyikapi arus perubahan (Nurcholis, 1997). Perubahan yang dimaksud pada saat ini yaitu munculnya sebuah pandemi Covid-19 yang menimbulkan kekhawatiran pada banyak bidang. Pandemi Covid-19 ini mampu merubah berbagai tatanan dan stuktur kegiatan masyarakat dari yang semula bebas menjadi lebih terbatas terutama dari segi ruang. Hal ini dilakukan karena sebuah virus dapat dengan mudah menular melalui kontak sosial sehingga upaya pencegahan yang menjadi solusi yaitu meminimalisir kontak sosial. Adanya berbagai pembatasan dengan pertimbangan merebanknya virus Covid-19 mau tidak mau memaksa pesantren beraadptasi dengan berbagai perubahan yang terjadi. Sistem pengelolaan dan manajemen di pondok pesantren Al-Falah Banjar Baru harus ikut beradaptasi dengan menerapkan berbagai kebijakan baru. Oleh karena itu, harus terdapat sebuah manajemen dan pengelolaan terpadu dalam sebuah pesantren sehingga tercipta integrasi yang sistematis dari semua elemen yang terkait pada pesantren untuk menghadapi adanya pandemi Covid-19.

Manajemen dapat diartikan sebagai upaya pengelolaan untuk mencapai tujuan tertentu (Asifudin, 2016). Seiring perkembangan waktu, manajemen pada pondok pesantren juga berjalan dinamis dan berubah mengikuti dinamika sosial yang terjadi dalam masyarakat secara global (Kahfi \& Kasanova, 2020). Adanya manajemen ini dilakukan dengan tujuan untuk memantau proses berjalannya pesantren dengan harapan dapat mengembangkan dan memajukan sebuah lembaga pondok pesantren. Pada situasi Covid-19 bentuk adaptasi yang dilakukan oleh pesantren yaitu dengan mengubah sistem pengelolaan atau manajemen pondok pesantren. Kehadiran pandemi Covid-19 dapat dikatakan benar-benar menggeser tatanan pembelajaran yang telah diterapkan sbeelumnya. Salah satu bentuk adaptasi tersebut yaitu perubahan sistem belajarmengajar yang semula tatap muka menjadi pembelajaran daring (UNICEF, 2020). Proses pembelajaran daring ini melibatkan berbagai platform digital dan aplikasi penunjang pembelajaran seperti video conference berupa Zoom meeting, google meet, Webex ataupun media pembelajaran lain seperti google clasroom, kahoot, Quizizz, dan berbagai platform lainnya yang mendukung pembelajaran. Pembelajaran yang tidak lagi tatap muka secara langsung (luring) tentunya menimbulkan problematika bagi guru dalam melakukan evaluasi dan observasi terkait perkembangan belajar pada peserta didik atau santri karena berbagai kegiatan berada di luar pengawasan guru ataupu ustadz. Aspek yang cukup menonjol dan menjadi permasalahan yang krusial yaitu terkait kedisiplinan. Kedisiplinan merupakan salah satu ajaran yang ditanamkan di pondok pesantren dan setiap santri dilatih untuk selalu disiplin, namun dalam perubahan manajemen pondok pesantren saat ini, aspek kedisiplinan menjadi sulit ditinjau. Terutama berkaitan dengan ketepatan waktu menghadiri kegiatan belajar mengajar secara daring maupun pengumpulan tugas karena akses internet pada 


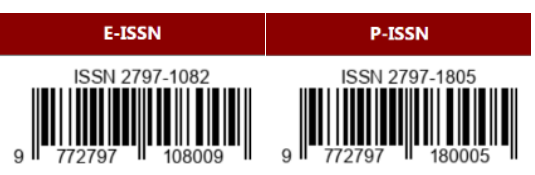

berbagai wilayah tidak dapat disama ratakan. Kendala tersebut tidak hanya menimpa satu pesantren saja, melainkan hampir di seluruh pesantren yang ada. Pesantren Al-Falah termasuk pondok pesantren yang juga mengalami kendala serupa. Pondok Pesantren yang terletak di Kelurahan Landasan Ulin Tengah, Kecamatan Liang Anggang, Kota Banjarbaru, Kalimantan Selatan tersebut juga menerapkan kebijakan baru selama pandemi Covid-19 berlangsung.

Berdasarkan berbagai pemaparan masalah di atas, maka penulis menaruh ketertarikan untuk menyelami lebih dalam terkait sistem pengelolaan atau manajemen yang diterapkan di Pondok Pesantren Al-Falah Banjar Baru pada masa pandemi Covid-19 ini.

\section{Metode}

Pada penelitian ini, penulis memberikan batasan objek dan memfokuskan objek kajian pada manajemen pendidikan di Pondok Pesantren Al-Falah Banjarbaru. Pendekatan yang dilakukan dalam penelitian ini yaitu penelitian kualitatif yang mencangkup upaya menelaah data empiris yang menggambarkan makna keseharian secara problematis dalam kehidupan yang dijabarkan dengan pengambilan data berupa hasil kualitatif (Fitriyah \& Luthfiyah, 2018). Pendekatan kualitatif ini biasanya bertujuan untuk menjabarkan atau mendeskripsikan sesuatu dengan metode analisis yang menekankan aspek alamiah dari rangkaian peristiwa yang diamati. Menurut Sawiningsih (2020) prosedur penelitian dengan pendekatan kualitatif akan menghasilkan data deskripsi berupa tulisan maupun ucapan hasil pengamatan subjek itu sendiri (Sawiningsih, 2020). Untuk jenis penelitian sendiri merupakan penelitian deskriptif yang mengambarkan menajemen pendidikan pesantren pada Pondok Pesantren Al-Falah Banjarbaru selama pandemi Covid-19. Untuk metode penelitian yang digunakan yaitu observasi pada objek terkait. Metode observasi yang dilakukan yaitu berupa metode mengamati sekaligus mencatat gelaja yang timbul dan tampak pada objek kajian yang diteliti (Hariani, 2019). Observasi ini dilakukan dengan objek berupa Pondok Pesantren Al-Falah dengan melakukan pengamatan dan pengumpulan informasi untuk memantau perkembangan manajemen pendidikan pada pesantren Al-Falah Banjarbaru. Penelitian ini menganalisis proses pendidikan dan pelaksanaan pendidikan di Pondok Pesantren Al-Falah selama pandemi dengan hasil berupa laporan tertulis hasil pengamatan dan olah studi literatur.

\section{Hasil dan Diskusi}

a. Manajemen Pendidikan

Manajemen diambil dari bahasa Inggris berupa manage yang bermakna mengurus, mengatur, mengelola dan melaksanakan. Menurut para ahli, manajemen dapat didefinisikan menurut (Budiwibowo \& Sudarmiani, 2018) sebagai berikut.

1. Davis mendefinisikan bahwa manajemen merupakan sebuah fungsi dari setiap kepemimpinan eksekutif dimanapun.

2. Millet mendefinisikan bahwa manajemen merupakan proses dalam memimpin dan melancarkan pekerjaan dari orang-orang yang terorganisir baik secara formal dalam kelompok dengan harapan mencapai tujuan yang diharapkan.

3. Mary Parker Follet dalam handoko mendefinisikan bahwa manajemen merupakan sebuh seni dalam menyelesaikan pekerjaan orang lain yang mengandung arti bahwa manajer bertugas mengatur dan mengarahkan orang lain dalam mencapai tujuan organisasi.

4. Luther Gulick mendefiniskan bahwa manajemen merupakan ilmu yang dipandang sebagai suatu bidang pengetahuan yang secara sistematis memahami mengapa sekaligus bagaimana orang bekerja.

5. Dale mengutip dan mendefiniskan bahwa manajemen merupakan kegiatan mengelola orang-orang, mengambil keputusan serta proses mengorganisasi memakai sumbersumber dalam menyelesaikan tujuan yang telah ditentukan.

Dari beberapa pemaparan pengertian tersebut dapat disimpulkan bahwa manajemen merupakan sebuah proses yang meliputi perencanaan, pengorganisasian, pengelolaan, pengarahan dan pengawasan sebagai upaya menggapai tujuan yang ditentukan. Dalam sektor pendidikan, proses manajemen difokuskan pada aktivitas sistematis terhadap sumber daya pendidikan agar terpusat pada usaha mencapai tujuan pendidikan. Sehingga dalam hal ini manajemen pendidikan dapat diartikan sebagai proses pengelolaan pada pendidikan. Dengan demikian, sebuah proses manajemen pendidikan merupakan rangkaian kegiatan yang dilakukan berulang dengan 


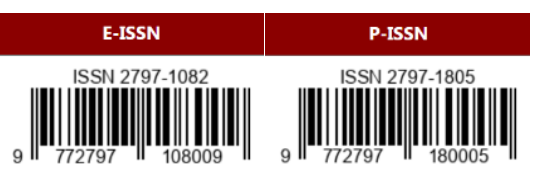

upaya saling mengawasi, mempengaruhi, mengarahkan sehingga seluruh aktivitas dan kinerja dapat memenuhi tujuan pendidikan yang hendak dicapai. Manajemen pendidikan dapat juga diartikan sebagai sebuah seni ataupun ilmu dalam pengelolaan sumber daya pendidikan sebagai upaya mencapai tujuan pendidikan secara efektif dan efisien (Asifudin, 2016). Manajemen pendidikan ini meliputi berbagai proses seperti merencanakan (planning), mengorganisasi (organizing), mengarahkan (directing), mengoordinasi (coordinating), mengawasi (controling) dan mengevaluasi (evaluation) (Budiwibowo \& Sudarmiani, 2018).

\section{b. Pondok Pesantren Al-Falah}

Pondok pesantren ialah sebuah lembaga pendidikan yang diakui oleh pemerintah dengan prinsip yang setara dengan pendidikan formal. Pengakuan dari pemerintah ini dapat dibuktikan dengan dimasukkannya pondok pesantren sebagai sistem pendidikan nasional yang termuat dalam Undang-Undang Sistem Pendidikan Nasional (Sisdiknas) (Hasanah, Alfi, \& Kurniasih, 2020). Pengakuan lain juga telihat dari adanya Kementrian Agama Republik Indonesia melalui sebuah pendirian Direktorat Diniyah dan Pondok Pesantren sebagai perwujudan pemerintah dalam upaya menaungi pendidikan berbasis agama.

Pondok pesantren yang dikaji dalam penelitian adalah Pondok Pesantren Al-Falah. Pondok Pesantren Al-Falah merupakan sebuah pesantren yang terletak di Jalan Ahmad Yani RT. 006 RW. 002 Kelurahan Landasan Ulin Tengah, Kecamatan Liang Anggang, Kota Banjarbaru, Kalimantan Selaran. Pondok Pesantren Al-Falah didirikan pada tanggal 26 Juli 1975 yang bertepatan dengan tanggal 06 Rajab 1395 Hijriah. Nama Al-Falah diambil dari lafadz adzan "hayya alal falah" yang memiliki makna "marilah menuju kepada keberuntungan". Dapat diartikan bahwa pendirian pondok pesantren dimaksudkan sebagai sebagai doa agar orang di yang berada di dalam pesantren beserta mereka yang menimba ilmu di Pondok Pesantren Al-Falah selalu mendapatkan keberuntungan dan keselamatan di dunia dan akhirat. Pendidikan yang diterapkan untuk santri yang menimba ilmu memiliki tiga jenjang pendidikan yang dapat ditempuh selama 7 tahun dengan rincian
(1) tingkat Tajhizi (persiapan) ditempuh selama satu tahun

(2) tingkat Wustha (menengah) ditempuh dalam waktu tiga tahun

(3) tingkat Ulya ditempuh dalam waktu tiga tahun.

Pondok Pesantren Al-Falah didirikan oleh seorang ulama bernama K.H.M Sani dengan pendiri lainnya yang bertekad untuk memajukan pendidikan terutama di pesantren. Menurut K.H.M Sani, pondok pesantren memiliki dua fungsi yaitu

(1) Sebagai Center of Excellence, yang menangani kader-kader pemikir agama

(2) Sebagai Agent of Development, yang menangani pembinaan pemimpin masyarakat terutama di pedesaan

Dengan pendirian Pondok Pesantren Al-Falah diharapkan dapat menjadi lembaga pengkaderan umat Islam yang lebih maksimal dengan hasil yang efektif dan efisien. Disamping itu, pendirian Pondok Pesantren Al-Falah juga bertujuan sebagai bentuk antisipasi dari akses negatif yang mungkin menyerang anak-anak.

c. Manajemen Pondok Pesantren Al-Falah di Masa Pandemi

Fungsi manajemen pada lembaga pendidikan berupa pondok pesantren akan dijabarkan sebagai berikut.

1. Perencanaan (Planning)

Perencanaan dapat diartikan sebagai rangkaian proses manajemen yang dilakukan sebagai gambaran masa depan untuk menggapai tujuan yang hendak dicapai. Pada pondok pesantren, proses perencanaan ini menjadi sangat penting terutama rencana jangka panjang (Asifudin, 2016). Hal ini dilakukan agar sebuah pondok pesantren memiliki jalan yang lebih baik, terarah serta tepat sasaran. Perencanaan dapat dijadikan pedoman agar dalam proses berjalannya kegiatan di pondok pesantren memiliki tuntunan sehingga tidak berjalan tanpa arah. Apabila sebuah pondok pesantren tidak memiliki perencanaan maka pesantren memiliki kemungkinan berjalan di tempat, mudah terbawa arus dan tidak mencapai tujuan atau bahkan salah arah. Penjabaran dari perencanaan ini dapat diwujudkan melalui adanya visi, misi dan tujuan pondok pesantren. 


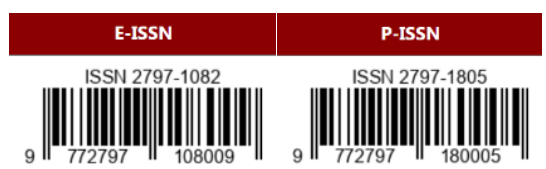

Dalam hal ini, Pondok Pesantren AlFalah memiliki Visi, Misi dan Tujuan Pendidikan yang akan dijabarkan sebagai berikut.

Visi Pondok Pesantren Al Falah

"Penguasaan ilmu fardhu 'Ain dan kifayah mengakar di tengah masyarakat, berorientasi kepada imtaq dan iptek menuju hidup mandiri."

\section{Misi Pondok Pesantren Al-Falah}

a. Melaksanakan amanat akidah ahlussunnah wal jama'ah melalui pengembangan pendidikan secara kualitatif dan kuantitatif

b. Memberdayakan kader perjuangan muslim yang berwawasan ahlussunnah wal jama'ah

c. Mengembangkan potensi kemanusiaan dengan segala dimensinya, baik dimensi intelektual, moral, ekonomi, sosial, dan kulturan dalam rangka menciptakan SDM yang handal

Tujuan jangka panjang Pondok Pesantren AlFalah adalah untuk menyiapkan generasi muda yang mampu menghadapi tantangan zaman.

\section{Pengorganisasian (Organizing)}

Pengorganisasian merupakan kegiatan yang terdiri dari kumpulan individu dalam rangkai menggapai tujuan tertentu. Pondok pesantren dalam melakukan pengorganisasian berlandaskan pada Undang-Undang Yayasan Tahun 2001 dan 2004 yang diimplementasikan pada tahun 2007 untuk dapat memberikan peluang pada pondok pesantren dalam rangka merekontruksi pengelolaan sehingga dapat diterapkan sesuai ilmu serta konsep manajemen yang baik dan benar. Kegiatan pengorganisasian ini memiliki titik fokus pada optimalisasi kualitas individu atau disebut juga dengan sumber daya manusia dengan melakukan pembinaan dan pengembangan yang diwujudkan dengan kegiatan pengarahan, briefing, diklat, sanksi, hukuman, penghargaan dan lainnya.

\section{Pengarahan dan Penggerakan (Directing,} Actuating)

Kegiatan pengarahan dan penggerakan biasanya diwujudkan dalam bentuk rapat dimana dapat dilakukan secara lebih leluasa dengan kunci adanya kepemimpinan dan komunikasi. Dalam hal ini, kegiatan pengarahan dilakukan ketika membahas kebijakan pada pondok pesantren seperti kebijakan yang perlu dirumuskan untuk menghadapi tantangan pandemi Covid-19.

\section{Pengontrolan (Controlling)}

Pada aktivitas pengontrolan ini dilakukan pengawasan terkait proses pendidikan agar pelaksanaan yang dilakukan sesuai dengan hasil serta tujuan yang menjadi perencanaan sebelumnya. Kegiatan pengontrolan ini dapat dilaksanakan melalui kegiatan laporan yang rutin dilaksanakan baik yang dilakukan tiap triwulan, caturwulan maupun persemester dan LPJ akhir tahun.

Pada manajemen Pondok Pesantren terdapat beberapa bentuk adaptasi terhadap pandemi Covid-19 sebagai wujud upaya bertahan dengan kebijakan-kebijakan baru yang dipertimbangkan demi kebaikan. Beberapa bentuk adaptasi manajemen Pondok Pesantren Al-Falah Banjarbaru meliputi.

\section{Perubahan sistem pembelajaran}

Pada masa sebelum pandemi, sistem pembelajaran di Pondok Pesantren Al-Falah dilakukan dengan tatap muka di ruang-ruang kelas. Sistem pembelajaran merupakan sebuah proses kegiatan belajar mengajar dimana bertujuan untuk menyampaikan ilmu dan informasi. Pada umumnya sebuah pondok pesantren identik dengan sorogan, bandungan, hafalan dan kedisiplinan (Abdurrahman, 2017). Namun, dalam masa pandemi ini Pondok Pesantren Al-Falah memutuskan dalam melakukan berbagai kegiatan dan tujuan pendidikan dilakukan secara daring untuk memutus kontak sosial. Hal ini dilakukan demi keamanan dan keselamatan pihak pesantren, santri, maupun pengajar. Oleh karena itu, selama pandemi Covid19 Pondok Pesantren memutuskan untuk mengubah sistem pembelajaran dari luring dan tatap muka menjadi daring melalui berbagai media video conference, chatting, maupun pengerjaan tugas-tugas yang dikumpulkan secara online juga. Selain 


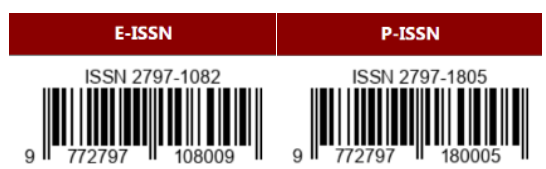

itu, untuk tetap mencapai tujuan pendidikan di pondok maka kegiatan yang dilakukan juga harus tetap berjalan seperti aktivitas mengaji online. Pada adaptasi pembelajaran online ini baik guru maupun santri dan orang tua dituntut untuk dapat mendukung proses pembelajaran online dengan menguasai teknologi sehingga proses pembelajaran berlangsung lancar. Orang tua juga berperan aktif untuk memberikan dukungan kepada santri agar memberikan pelayanan baik teknologi penunjang pembelajaran maupun akses internet. Sedangkan guru atau ustadz dapat berusaha memaksimalkan kemampuan mengoperasikan teknologi sehingga dalam proses menyampaikan ilmu lebih lancar dan bertanggung jawab mempersiapkan materi dan hal lain terkait online home learning.

Dapat dikatakan bahwa kunci keberhasilan dalam proses pembelajaran daring adalah adanya kolaborasi antara orang tua, santri maupun pengajar dengan baik. Proses pembelajaran daring memang kurang optimal dan kurang efektif apabila dikemas kurang baik. Pembelajaran daring berisiko membuat santri merasa jenuh dan cepat bosan bahkan pembelajaran yang berlangsung tidak menyentuh aspek afektif maupun psikomotorik. Gangguan pada pembelajaran daring juga lebih banyak mulai dari keterbatasan teknologi, gangguan internet dan sinyal serta kurangnya dukungan orang tua. Dalam hal ini harus terjadi sinergi yang kuat agar proses pembelajaran daring dapat berjalan optimal. Orang tua dapat menyiapkan diri menjadi pendamping santri dalam kegiatan belajar mengajar juga memberikan fasilitas seperti sumber belajar pada pembelajaran daring, sedangkan pengajar dapat meningkatkan inovasi dalam pembelajaran sehingga penyampaian pembelajaran lebih kreatif dan menarik bagi santri. Lembaga pendidikan seperti pesantren dalam kasus ini dituntut untuk memberikan pembelajaran yang efektif dan cocok dilaksanakan pada pembelajaran daring.

Pada masa pandemi ini, Pondok

Pesantren Al-Falah juga sudah mulai menerapkan sistem pembelajaran secara tatap muka namun menerapkan protokol kesehatan sebaik mungkin. Sebelum melakukan pembeljaran tatap muka, santri yang kembali ke pesantren melewati berbagai tahap persiapan yang ketat seperti karantina mandiri, membawa surat karantina, surat kesehatan dan hasil SWAB. Juga terdapat aturan lain seperti kewajiban diantar orang tua dengan kendaraan pribadi, kewajiban memastikan kesehatan santri dan mempersiapkan keperluan pribadi sebagai bentuk antisipasi penularan Covid-19. Bahkan pada masa pandemi ini, Pondok Pesantren Al-Falah menambahkan aktivitas baru berupa senam kesehatan yang dilaksanakan pukul 10.00 dengan tetap menerapkan social distancing antar siswa. Walaupun pembelajaran tersebut masih memberikan kelonggaran kepada santri dengan pertimbangan orang tua dan segi keselamatan sehingga pembelajaran tatap muka ini tidak wajib bagi santri yang tidak dapat terjun langsung di Pondok Pesantren. Sebagai gantinya santri tetap dapat mendapatkan pembelajaran melalui daring. Untuk kegiatan ulangan sendiri Pondok Pesantren Al-Falah menerapkan sistem full online baik santri yang mengikuti pembelajaran daring maupun luring.

2. Kurikulum pendidikan pondok pesantren

Pada masa sebelum pandemi, kurikulum pendidikan Pondok Pesantren Al-Falah seperti proses kegiatan pada umumya yang sudah diatur dalam jadwal kegiatan sehari-hari. Namun, dalam masa pandemi ini jadwal pembelajaran dan kegiatan yang seharusnya dilakukan menjadi tidak teratur. Oleh karena itu, kurikulum pendidikan di pondok pesantren dilakukan sesuai kurikulum lama namun jadwal yang diatur dipangkas sehingga menghemat biaya internet dengan memadatkan jam-jam pelajaran sesuai kebutuhan. 
3. Sistem pembiayaan

Sistem pembiayaan pada Pondok Pesantren Al-Falah juga harus diadaptasikan. Apabila sebelumnya akomodasi yang diperlukan oleh santri adalah tempat tidur, makan sehari-hari dan kebutuhan pendidikan pesantren maka dengan pembelajaran secara daring pembiyaan terkait hal tersebut tentu saja berkurang bahkan tidak ada. Sebagai gantinya, Pondok Pesantren AlFalah memberikan subsidi internet untuk guru, uztadz maupun santri sebagai adaptasi hal yang paling dibutuhkan dalam pembelajaran daring. Internet merupakan akses yang wajib digunakan dan memiliki pengaruh besar pada pembelajaran secara daring, sehingga Pondok Pesantren Al-Falah mengalihkan pembiayaan pada pihak yang terlibat dalam bentuk pulsa ataupun paket internet.

\section{Fasilitas Pondok Pesantren}

Sebagai bentuk adaptasi dengan pandemi Covid-19, Pondok Pesantren Al-Falah Banjarbaru juga melakukan pengelolaan pada fasilitas pondok pesantren yang mendukung protokol kesehatan. Hal ini ditunjukkan dengan penerapan protokol kesehatan secara ketat baik pada awal PSBB hingga pandemi berupa menempatkan spot cuci tangan di berbagai titik pondok pesantren, mewajibkan pemakaian masker pada wilayah pondok, menjaga jarak, dan pembatasan jam kunjungan pondok. Kebijakan-kebijakan tersebut merupakan afirmasi baru di Pondok Pesantren Al-Falah sebagai upaya menghadapi pandemi Covid-19 agar kegiatan di pesantren tetap berjalan dan tujuan pendidikan tetap tercapai tanpa mengesampingkan keselamatan semua pihak. Fasilitas lain yang disediakan oleh pondok yaitu penyemprotan desinfektan secara berkala, penyediaan handsanitizer, menyediakan ruang isolasi, menyediakan tim kesehatan yang bertugas dalam kegiatan skrining, menyediakan tempat mandi ataupun wudhu dengan air yang mengalir serta menyiapkan alat pelindung diri bagi petugas.

\section{Kebijakan Protokol Kesehatan}

Pada masa pandemi ini, Pondok Pesantren Al-Falah menerapkan protokol kesehatan yang ketat dengan tujuan agar seluruh pihak dalam pesantren juga masyarakat dapat melakukan aktivitas dengan lebih aman juga sehat tanpa membahayakan keamanan dan kesehatan orang lain. Hal ini dimuat juga dalam surat keputusan Menteri Kesehatan Republik Indonesia Nomor. Hk.01.07/Menkes/2332/2020 tentang panduan pemberdayaan masyarakat pesantren dalam pencegahan dan pengendalian Covid-19. Pada surat tersebut, dinyatakan bahwa protokol kesehatan merupakan sebuah ketetapan yang wajib ditaati leh segala pihak agar mampu beraktivitas kembali secara aman pada saat pandemi Covid19. Apabila Pondok Pesantren Al-Falah menerapkan protokol kesehatan dan menaati aturan yang tertera, maka dapat meminimalisir penularan Covid-19 yang mungkin terjadi. Dalam hal ini, Pondok Pesantren Al-Falah menerapkan protokol kesehatan dengan cukup ketat seperti kewajiban memakai masker di wilayah pesantren, membersihkan lingkungan dengan desinfektan secara berkala, menerapkan etika bersin yang benar, menyediakan spot cuci tangan dan membiasakan diri mencuci tangan serta melakukan kegiatan fisik seperti senam pagi namun tetap menjaga jarak.

\section{Kesimpulan dan Saran}

Manajemen pendidikan merupakan rangkaian kegiatan yang dilakukan berulang dengan upaya saling mengawasi, mempengaruhi, mengarahkan sehingga seluruh aktivitas dan kinerja dapat memenuhi tujuan pendidikan yang hendak dicapai. Pada masa pandemi ini, Pondok Pesantren Al-Falah sudah melakukan manajemen pengelolaan pondok dengan mematuhi protokol kesehatan dan menerapkan berbagai kebijakan dengan berbagai pertimbangan kebaikan bersama. Beberapa kebijakannya yaitu pembelajaran daring, mengaji online, pembelajaran tatap muka dengan protokol kesehatan ketat, penyediaan fasilitas menunjang kebersihan, dan subsidi internet. Pada penerapan manajemen pesantren, sebaiknya tetap memberikan ilmu dan pendidikan dengan berkualitas seperti pembelajaran sebelum 
pandemi tanpa mengesampingkan keselamatan santri dan pengajar. Oleh karena itu, sebaiknya Pondok Pesantren menyusun kebijakan yang inovatif agar santri tetap mendapatkan tujuan pendidikan di pesantren secara aman dan nyaman sebagai bentuk pertahanan di masa pandemi.

\section{Daftar Pustaka}

Abdurrahman. (2017). Impelementasi Manajemen Kurikulum Pesantren Berbasis Pendidikan Karakter. At-Turas, 4(2) : 119.

Asifudin, A. J. (2016). Manajemen Pendidikan untuk Pondok Pesantren. Jurnal Manajemen Pendidikan Islam, 1(2) :355367.

Budiwibowo, S., \& Sudarmiani. (2018). Manajemen Pendidikan. Yogyakarta: Andi.

Fitriyah, M., \& Luthfiyah. (2018). Metodologi Penelitian. Sukabumi: CV Jejak.

Hariani, N. (2019). Ppenerapan Metode Role Playing untuk Meningkatkan Hasil Belajar Siswa pada Materi Perkembangbiakan Makhluk Hidup. Jurnal Ilmiah Pendidikan Agama dan Kebudayaan Hindu, 10(2) : 63-74.

Hasanah, D., Alfi, A., \& Kurniasih, D. (2020). Kebijakan Pendidikan di Pondok Pesantren Al-Muayyad Surakarta Selama Masa Pandemi Covid19. Jurnal Pendidikan, 60-75.

Kafrawi, H. (1978). Pembaharuan Sistim Pendidikan Pondok Pesantren sebagai Usaha Peningkatan Prestasi Kerja dan Pembinaan Kesatuan Bangsa. Surabaya: Cemara Indah.

Kahfi, S., \& Kasanova, R. (2020). Manajemen Pondok Pesantren di Masa Pandemi Covid-19 (Studi Pondok Pesantren Membaul Ulum Kedungadem Bojonegoro). Jurnal Pendidikan Berkarakter, 3(1) : 26-30.

Mukri, S. G. (2020). Modernisasi Sistem Pendidikan di Pesantren. Jurnal Agama Islam, 1-19.

Nurcholis. (1997). Bilik Bilik Masjid. Jakarta : Paramadina.

Sawiningsih, S. (2020). Penggunaan Metode Penemuan Untuk Meningkatkan Ketuntasan Belajar Siswa Mata Pelajaran
Matematika pada Konsep Penjumlahan Kelas II Semester I SDN Bedoro 2 Sambungmacan. Jurnal Ilmu Pendidikan Fakultas Keguruan dan Ilmu Pendidikan Universitas Sebelas Maret Surakarta, Vol.

https://doi.org/10.1093/occmed/kqq062.

Sunaryo, P. (2020). Pengembangan Manajemen Kurikulum Pondok Pesantren Modern Adh-Duha Berbasis Yatim dan Dhuafa. Jurnal Tarbawi, 17(1): 2088-3102.

UNICEF. (2020). COVID-19 dan Anak-Anak di Indonesia Agenda Tindakan untuk Mengatasi Tantangan Sosial Ekonomi. In Journal of Education Pshycology and Counseling, 2 (1) Retrieved from www.unicef.org. 